\title{
Integration in the New Pact on Migration and Asylum: A Key Element of a Successful Migration Policy, but no EU Legislative Competence
}

\section{Ulrike Brandl"}

\section{Introduction}

Integration in European Union migration policy is a topic characterised by the gap between the lack of legislative competence of the $\mathrm{EU}^{1}$ and the essential importance of comprehensive, effective and targeted integration measures for a successful migration policy. Integration has always been a key element for a prosperous relation between citizens and immigrants and gained more importance in the aftermath of the so-called refugee crisis in 2015 and 2016, when even the cohesion of societies seemed endangered by the increase of refugees and migrants intending to take up long-term residence in Member States. In practice, the design of integration measures as a prerequisite for residence titles and the difficulty to pass integration (language) tests is a core debate in many Member States. ${ }^{2}$

The ongoing efforts for a recast of the EU migration legislation are accompanied by a strategy to support and strengthen national integration policies. The New Pact on Migration and Asylum presented by the European Commission on $23^{\text {rd }}$ September 2020 contains a separate chapter

* Ass.-Prof. at the University of Salzburg.

1 Article 79 (2) TFEU provides the legal basis for the adoption of measures in the following areas: (a) the conditions of entry and residence, and standards on the issue by Member States of long-term visas and residence permits, including those for the purpose of family reunification; (b) the definition of the rights of third-country nationals residing legally in a Member State, including the conditions governing freedom of movement and of residence in other Member States; (c) illegal immigration and unauthorised residence, including removal and repatriation of persons residing without authorisation; (d) combating trafficking in persons, in particular women and children. Consolidated Version of the Treaty on European Union [2008] OJ C115/13.

2 See Report from the Commission to the European Parliament and the Council on the implementation of Directive 2003/86/EC on the right to family reunification, COM[2019] 162 final, 29 March 2019. 
with the title "Supporting integration for more inclusive societies". ${ }^{3}$ The reference to inclusive societies shows the socio-political importance of integration. The success of integration policies is a decisive factor for the acceptance of the legislative acts by Member States and finally for an effective national implementation.

Chapter 8 of the New Pact enumerates a number of recommendations for Member States to promote integration. The Pact announced the elaboration of a new Action Plan on Integration and Inclusion 2021 - 2027, which was published by the Commission on $24^{\text {th }}$ November $2020 .{ }^{4}$ The Action Plan is a comprehensive document, which stresses key principles and values regarding integration and inclusion and focuses on actions in main sectoral areas like education and vocational training, employment and skills, health and housing.

This contribution intends to give an insight into the development of integration policies in the EU and into the content of the Pact and the Action Plan on Integration and to highlight several critical issues. These are the unstructured reference to rights of migrants deriving from legally binding obligations and measures which should be implemented to support a successful integration. It would have been better to confirm that rights have to be guaranteed without discrimination and that supporting measures are intended to provide assistance for full inclusion. Furthermore, the Pact and the Action Plan cover all migrants and even nationals with a migratory background. On the one hand, this approach can be seen as an inclusive one, as it refers to all aspects of a prosperous coexistence. On the other hand, it could lead to the effect that the measures are not targeted enough as they are designed to apply to diverse categories.

\section{Previous Efforts to Promote Integration}

The Action Plan 2021-2027 is the successor of the Action Plan 2016. The promotion of integration measures in the EU however started much earlier. Already the 1999 European Council in Tampere referred to the necessity to create a common integration policy. ${ }^{6}$ Under the heading "Fair

3 New Pact on Migration and Asylum, COM[2020] 609 final, 23 September 2020.

4 Action Plan on Integration and Inclusion 2021-2027, COM[2020] 758 final, 24 November 2020.

5 Action Plan on the integration of third country nationals, COM[2016] 377 final, 7 June 2016.

6 Tampere European Council, Presidency Conclusions, 15 and 16 October 1999. 
treatment of third country nationals" the Conclusions demanded fair treatment for those who reside legally on the territory of Member States. The Conclusions continued by referring to the aim that a "more vigorous integration policy should aim at granting them rights and obligations comparable to those of EU citizens". ${ }^{7}$ In 2004, the Council adopted the EU Common Basic Principles for Immigrant Integration Policy. ${ }^{8}$ These principles enumerated 11 short-worded basics for the development of future integration measures. The Justice and Home Affairs Council reaffirmed them in 2014. ${ }^{9}$ In 2011, the European Commission set out a European Agenda for the integration of third-country nationals. ${ }^{10}$

Already the EU Common Basic Principles pointed to the important fact that integration is a "two-way process" involving immigrants and residents of Member States. Principle 2 referred to the required respect for European values. The further principles included employment, basic knowledge of the host society's language, history and institutions, access to education and the participation of immigrants in the democratic process. Enabling immigrants to acquire basic knowledge of language, history and institutions, access for immigrants to institutions, as well as to goods and services equal to national citizens are enumerated as well. The Principles also stressed the importance of frequent interaction between immigrants and citizens.

In 2008, the Union also established a European Network on Migration (EMN) by a Council decision, which was later on amended by a regulation. ${ }^{11}$ This regulation provided for financing the network through the Asylum, Migration and Integration Fund. The alignment of integration measures with funding possibilities brought an important input into the development of integration projects in the Member States. EMN has the task to provide information on migration and asylum in order to support

7 Ibid, III.

8 Press Release, 2618th Council Meeting Justice and Home Affairs, Council Conclusions, Immigrant Integration Policy in the European Union, 19 November 2004.

9 Justice and Home Affairs Council Meeting Luxembourg, 5 and 6 June 2014. In these Conclusions the Council also referred to the fact that "integration is a long-term and multi-faceted process that takes place at a national, regional and local level and in which reception measures play an important role".

10 European Agenda for the Integration of Third-Country Nationals, COM[2011] 455 final, 20 July 2011.

11 Council Decision 2008/381/EC establishing a European Migration Network [2008] OJ L131/7. The decision was amended by Regulation (EU) 516/2014 establishing the Asylum, Migration and Integration Fund [2014] OJ L 150/168. 
policymaking in the European Union. EMN also informs the general public on migration and asylum. In 2017, the Commission and European social and economic partners signed the European Partnership for Integration. ${ }^{12}$ This partnership was established with the aim to foster the integration of refugees into the labour market. The Commission funded a variety of projects. Employers, chambers of industry and commerce, trade unions and migrant associations were supported in joining forces to reach the goal.

The European Partnership for Integration is an example of a set of targeted measures. The majority of previous documents (e. g. the Action Plan 2016 and many others) containing plans, ideas and concrete measures about the promotion of integration were characterized by a mixture of an enumeration of deficits in integration policy and ideas and recommendations about projects that are perceived as being supportive to successful integration. A further common characteristic is the fact that the documents did not distinguish between different categories of migrants. They referred to third country nationals in general, to persons who were granted asylum or subsidiary protection as well as to persons who intended to stay permanently or for a certain period for employment or for other reasons. Furthermore, the documents complained about the difficult situation with regard to access to employment, education and social inclusion in general. They lamented about these deficits without a clear distinction between rights which have to be guaranteed to third country nationals and other mainly supportive measures which make integration easier.

The Action Plan 2016 frequently referred to the situation in 2015/2016 with high numbers of persons seeking protection in the EU Member States. The Plan mirrored the difficult and demanding situation in 2016 and specified a number of aims. The text confirmed that the EU policy framework is designed to support States to develop and strengthen their national integration policies. The Commission announced to deliver operational and financial support. The Action Plan also provides for a review process carried out by the Commission.

The text discloses the discrepancy between EU citizens and third country nationals in the areas of employment, education and social inclusion. This discrepancy concerns the legal and also the factual situation. With regard to the conclusions drawn and the measures which should be adopt-

12 See 'A European Partnership for Integration' <https://ec.europa.eu/home-affairs/ system/files/2017-12/20171220_european_partnership_for_integration_en.pdf $>$ accessed 23 November 2021. 
ed there was however no clear distinction between rights of third country nationals which have to be guaranteed on the one hand and measures which are designed to support integration measures on the other. The text did not differentiate between legal obligations contained in International Law and national law such as the right to education, workers' rights and several social rights and other areas where migrants should have access to.

The wording of the Action Plan reveals a strong focus on the economic burdens caused by consequences of non-integration. The Commission clearly highlighted that it would be a waste of resources if migrants would not be integrated in time and that there "is a clear risk that the cost of non-integration will turn out to be higher than the cost of investment in integration policies". On the other hand, the Commission pointed to the fact that integration needs vary widely and have to be adapted accordingly. The Commission also stressed the necessity to take the situation of vulnerable groups into account and to design integration measures according to their needs. A further aim is to respect the interests of migrants and of receiving societies, to improve the welfare of all members of society and to create inclusive societies.

Part 4 of the Action Plan 2016 structured the measures useful for the integration process in the various phases of migration. It started with measures for the first phase, the so-called pre-departure or pre-arrival phase and then continued with the phase where migrants are already present in the receiving states and where access to education, to the labour market, to vocational training and to basic services are fundamental for successful integration. In this phase, migrants should be empowered to active participation and social inclusion in the receiving society. For each phase, the Commission announced the next steps to be realised by the Commission itself and encouraged Member States to conduct integration measures. The structure of this part would be useful and could lead to a more goal-oriented approach.

The Action Plan referred to the two main tools suitable to reach the aims. These are policy coordination and funding. Coordination and funding led to a number of successful integration projects in the following years. An overview of concluded and on-going integration projects is available here. ${ }^{13}$

The 2016 Action Plan is characterised by a variety of aims, by reference to a variety of areas where support is needed and by highlighting some

$13<$ https://ec.europa.eu/migrant-integration/eu-grid/implementation-2016-action-pla n-integration_en> accessed 16 December 2021. 
deficits existing and disparities between migrants' rights and the rights of nationals. It is also clearly visible that the Plan was published in a time of highly increased numbers of persons arriving and the challenges to host states and the societies in these states. Though we still see many deficits in Member States integration policies, the 2016 Action Plan was definitely an important step in framing integration policy. The Commission funded valuable projects to support the dialogue between migrants and citizens under the Horizon 2020 programme. ${ }^{14}$

\section{Chapter 8 of the New Pact on Migration and Asylum: Integration of Migrants Should Lead to More Inclusive Societies}

Chapter 8 of the Pact 2020 shapes the aims of integration. Everyone who is legally present in the EU should have the possibility to "participate in and contribute to the well-being, prosperity and cohesion of European societies". Chapter 8 repeats the unstructured reference to immigrants and to persons who have been granted asylum or subsidiary protection. To give an overview of numbers, the Commission referred to statistics which show that around 21 million non-EU nationals were legally resident in the EU in $2019 . .^{15}$

The text then again stresses the necessity to make a compromise and to adopt integration measures which are designed to give benefits to the "individuals concerned, and the local communities into which they integrate". This approach was already included in the 2016 Plan but receives more attention now.

The New Pact uses a different wording than previous documents on integration. It often mentions the importance of the European way of life but does not define it. This leads to the question of what exactly is the "European way of life"? One could assume that its basis can be found in Article 2 TEU. According to this article the "Union is founded on the values of respect for human dignity, freedom, democracy, equality, the rule of law and respect for human rights, including the rights of persons

14 Horizon 2020 Framework Programme $<$ https://ec.europa.eu/info/funding-tenders /opportunities/portal/screen/opportunities/topic-details/migration-09-2020;freeTe xtSearchKeyword=;typeCodes $=1$; statusCodes $=31094501,31094502$;programCode $=$ H2020; programDivisionCode $=31047893$;focusAreaCode $=$ null;crossCuttingPriorit yCode=null;callCode=Default;sortQuery $=$ openingDate;orderBy=desc;onlyTenders =false;topicListKey=topicSearchTablePageState $>$ accessed 23 November 2021.

15 Source of statistics in this paragraph: Eurostat. UK figures not included. 
belonging to minorities. These values are common to the Member States in a society in which pluralism, non-discrimination, tolerance, justice, solidarity and equality between women and men prevail. The Pact itself does not shed light on the notion "European way of life", the Action Plan 2021-2027 however goes into a few more details with regard to giving some contours to this notion.

The Pact repeats the enumeration of obvious deficits in various areas. These include unemployment, lack of educational or training opportunities and limited social interaction. The Commission then stresses that the integration of migrants should be a key element in the general EU agenda to promote social inclusion. In chapter 8 the Commission announced the intention to adopt an Action Plan on integration and inclusion for 2021-2024. It was adopted two months later with a timeframe from 2021 to 2027.

The Commission stresses the intention to provide strategic guidance and to set up concrete measures to foster inclusion. The areas covered are broader than previous ones and comprise social inclusion, employment, education, health, equality, culture and sport. The text however mainly enumerates the fields where integration is needed, the strategic guidance is still missing.

The text then continues with a slightly more structured approach than the Action Plan 2016. The Commission aims to make a distinction between rights and actions designed to guarantee full access to these rights and the support of integration in other areas. Migrants shall be enabled to "fully benefit from the European Pillar of Social Rights". The Commission also referred to the recent renewal of the European Partnership for Integration to offer opportunities for refugees to integrate into the European labour market.

The Commission announced to establish an informal expert group on the views of migrants. This group should also support the framing of the Action Plan 2021-2027. The first meeting of the expert group was already held on $13^{\text {th }}$ November 2020 and the group contributed to the preparation of the Action Plan 2021-2027.

\section{Action Plan on Integration and Inclusion 2021-2027}

The Action Plan 2021-2027 as well as previous documents enumerate a number of actions, programs and measures to support integration. The Actions Plan highlights the importance of inclusion and inclusive societies. It again refers to the European way of life and sheds some light on the 
content of the notion. The text emphasizes that the need to empower those facing disadvantages, to provide for equal opportunities for all to enjoy their rights and participation in community and social life are elements of the European way of life. Reference is also made to the respect for common European values as enshrined in EU Treaties and in the Charter of Fundamental Rights.

The Action Plan talks about the European way of life and about inclusive societies in general, but does not mention any possible negative consequences of integration for the immigrants such as the potential loss of identity of certain groups. The two-fold approach to make a compromise between migrants' rights and expectations and between the perceptions of receiving societies is a key element on the UN Global Compact on Migration as well. The Compact intends to create a mutual respect for customs, traditions and cultures of both societies. As already elaborated in a commentary to the GCM integration measures should not require assimilation but only respect of local traditions, customs and rules. ${ }^{16}$

The Action Plan does not define the notions integration and inclusion. In social sciences and other disciplines positive and negative effects of inclusion, integration and assimilation attract much more attention. The results of research in these disciplines should be integrated in the framing of integration policy. Several suggestions which are an excellent starting point for the discussion are the promotion of a feeling of togetherness having in mind that this feeling cannot be prescribed by legislation but has to develop within societies with the support of state policies and a holistic approach towards integration instead of highlighting specific elements. ${ }^{17}$

Part 2 contains a summary of previous integration efforts, presents results and shows statistics. Part 3 enumerates a number of key principles of integration policy. The Commission then highlights the need to respect rights but does not refer to details. It is interesting that the document again points to the European "Pillar of Social Rights" without going into details. The Social Pillar as an initiative launched by the European Com-

16 Ulrike Brandl, 'Progress made in integration and social inclusion: Objective 16 "Empower migrants and societies to realise full inclusion and social cohesion" in the review process' (Refugee Law Initiative Blog, 19 November 2018) <https://rli. blogs.sas.ac.uk/2021/02/18/progress-made-in-integration-and-social-inclusion-obje ctive-16-empowerment-of-migrants-and-societies-to-realize-full-inclusion-and-socia 1-cohesion-in-the-review-process/available> accessed 23 November 2021.

17 See Ilke Adam and Daniel Thym, 'Integration' in Philippe De Bruycker, Marie De Somer and Jean-Louis De Brouwer (eds), From Tampere 20 to Tampere 2.0: Towards a New European Consensus on Migration (European Policy Centre 2019). 
mission in 2017 refers to social rights for people across Europe but it is not specifically designed to improve access of migrants to social rights.

Member States are obliged to guarantee social, economic cultural rights to migrants. Restrictions are only allowed when they are justified and legitimate according to international and national law. Additional support and integration measures including incentives for a participation in these measures is helpful and should be promoted, there is however no legal obligation to grant the support.

Inclusion for all is one of the slogans of the Action Plan and this inclusion should not only focus on migrants but also on nationals with a migrant background. As already mentioned, the needs of persons with regard to integration and also the expectations of receiving societies vary widely and it would have been better to refer to the needs of different categories of persons in a structured way and not in a holistic approach.

A more nuanced approach is included in a special part of the Action Plan under the heading "targeted support where needed". This is a useful additional enumeration of specific needs of certain groups. It would however have been better to structure all the planned actions in this coordinated way. Under the mentioned heading, the Commission enumerates specific challenges for newly arrived migrants, challenges for Member States under migratory pressure and the protective needs of children, especially unaccompanied children.

Part 4 points to actions in main sectoral areas. This part contains a more structured approach to future integration measures in the sectors education and training, employment and skills and health and housing. In each section, the Commission announces measures to be enacted by the Commission itself and measures, which are recommended to Member States. This part of the Action Plan contains a comprehensive list of targets and actions.

The next part enumerates actions supporting effective integration. Again, funding is a central point in this enumeration. The Commission announced increased opportunities for EU funding under the 2021-2027 Multiannual Financial Framework. ${ }^{18}$ The budget for integration is included in the renewed Asylum, Migration and Integration Fund, the amount is $€ 9.882$ billion. ${ }^{19}$

18 Multiannual Financial Framework 2021-2027 <https:/ec.europa.eu/info/publicat ions/multiannual-financial-framework-2021-2027-commitments_en> accessed 23 November 2021.

19 Regulation (EU) 2021/1147 of the European Parliament and of the Council establishing the Asylum, Migration and Integration Fund [2021] OJ L 251/1. 
The Commission also announced a comprehensive monitoring and a mid-term review at the end of 2024. Furthermore, regular implementation reports analysing progress and highlighting areas of common challenges are foreseen. Furthermore, a new Eurobarometer on integration will be launched.

\section{EU Competence to Legislate}

The most important question in the area of integration is the lack of EU competence to legislate in the field of integration. In general, the European Union has a shared competence for developing a common immigration policy. Article 79(4) TFEU refers to the establishment of measures to provide incentives and support for the action of Member States with a view to promoting the integration of third-country nationals residing legally in their territories. Thus, only supportive measures may be adopted, harmonisation of laws and regulations is explicitly excluded. The Union may not use Article 352 TFEU as a legal basis either, as Article 352(3) again excludes harmonisation of Member States' laws or regulations.

The possibility to act is limited to support and to coordinate. Consequently, the aims mentioned and the initiatives planned can only be a recommendation to Member States. The Commission also has the possibility to fund integration projects and to establish institutions with the task to support integration. Soft law instruments are created based on a special form of intergovernmental policy-making - the open method of coordination (OMC).

\section{EU Efforts to Foster Integration and the Global Compact On Migration}

Integration and social inclusion are also key topics in the Global Compact for Safe, Orderly and Regular Migration ('GCM'). ${ }^{20}$ Objective 16 of the GCM aims to increase the empowerment of migrants and societies to realize full inclusion and social cohesion. It is astonishing that neither the

20 Global Compact for Safe, Orderly and Regular Migration, 13 July 2018, available on A/CONF.231/3 - E - A/CONF.231/3. The Compact was formally adopted at the Intergovernmental Conference to adopt the Global Compact for Safe, Orderly and Regular Migration, 10 - 11 December, Marrakech and later on adopted as a resolution by the UN General assembly, UNGA Res 73/195. 
New Pact nor the Action Plan refer to the GCM and its objective 16. In general, the response to the GCM and the follow up seem to be quite unimportant for the EU. The EU submitted a written contribution to the first review round held according to the monitoring process established by the Pact. The EU report is quite general and only points to progress made with regard to integration. ${ }^{21}$ The report refers to numerous activities, there is however no direct reference to the New Pact on Asylum and Migration in the (at that time still planned) Action Plan on Integration and Inclusion for 2021-2027 published by the Commission on $24^{\text {th }}$ November 2020 .

Several statements in the Basic Principles and in many other EU documents are still of core importance for a successful integration and are repeated in much more detail in the UN Global Compact on Migration.

\section{Conclusions}

In theory the added value of the new Action Plan is high as it refers to the most important sectors where integration support is essential. There are however several weaknesses. A shortcoming is the unstructured approach with planned integration measures for all migrants and also EU citizens with migrant background. Furthermore, the Action Plan does not distinguish between rights which have to be granted to migrants and voluntary additional supportive integration measures. The Action Plan 2021-2027 stresses the notions European way of life and inclusive societies in general, but does not mention any possible negative consequences of integration measures.

The New Pact and the Action Plan 2021-2027 again reveal the challenges with regard to integration. The Action Plan is an ambitious enumeration of actions and measures to be implemented by the Commission and comprehensive encouragements to Member States. If and how Member States follow these plans will depend also depend on financial support by EU funding and on their own vision of integration as a cornerstone of a successful migration policy.

21 Contribution by the EEAS/European Commission Services to the Regional Review of the Global Compact for Safe, Orderly and Regular Migration in the UNECE Region (12-13 November 2020). 